\title{
Correlates Attitude towards Adoption and Re-Invention Technology of Small Rubber Farmers in Dhalai District of Tripura, India
}

\author{
Kharendra Reang ${ }^{1}$, Samir Ranjan Dash ${ }^{2 *}$ and Amitava Biswas ${ }^{3}$ \\ ${ }^{1}$ Department of Agriculture Extension, PSB, Visva-Bharati, Sriniketan, WB, India \\ ${ }^{2}$ Agril. Extn, Krishi Vigyan Kendra, Jagatsinghpur, OUAT, Bhubaneswar, Odisha, India \\ ${ }^{3}$ Department of Agriculture Extension, BCKV, WB, India \\ *Corresponding author
}

\section{A B S T R A C T}

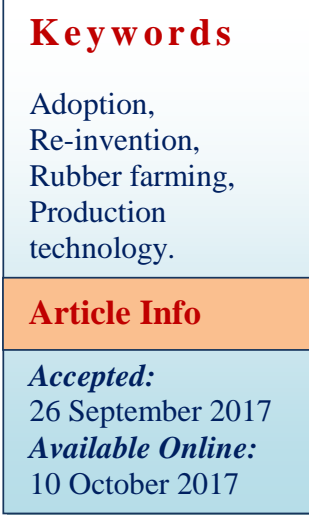

Keywords

Adoption,

Re-invention,

Rubber farming,

Production

Article Info

Accepted:

Available Online:

10 October 2017
Rubber constitutes one of the main cash crops in tiny state of Tripura owing to favorable climatic condition. The use of production technologies are being generalized in rubber smallholdings though the extent of its adoption and re-invention remains quite variable. In this paper, an attempt was made to correlates the farmers' adoption and re-invention attitude of small rubber farming community in Manu block under Dhalai district of Tripura. The study revealed that majority of the rubber growers are show Favorable attitude towards adoption rubber farming and the correlation analysis depicts that variables like age, education, farm mechanization, off farm income and annual income have been found significant which facilitated the appropriation of the reinvention and that fostered its adoption.

\section{Introduction}

Rubber is one of the major plantation crops in Tripura since it was raised for the first time in Tripura in 1963 by the State Forest Department. Tripura Forest Development \& Plantation Corporation Ltd. (TFDPC), a State Government Undertaking established in 1976, adopted rehabilitation of degraded forests through rubber plantation as its primary objective. Rubber has been identified as one of the thrust areas in Tripura, in view of its suitability to the terrain and the acceptability amongst the people. Tripura now stood as a second largest rubber growing state of India after Kerala both in terms of area as well as production and has emerged as the forerunner among the non-traditional rubber growing regions with 61231 ha of plantation and 37277 tonnes of production in 2012-13 (Govt of Tripura, 2015). Rubber plantation has taken a paradigm shift in shaping the standards of livelihood systems and thus secured a way for farmers to gain constant income. The relative success of rubber in Tripura can be attributed to its economic viability; effective extension and institutional support in production and marketing by the Rubber Board; along with the decline and uncertainty in tea and horticulture crops 
(Viswanathan and Bhowmik, 2014). Even though the rubber cultivation has spread up in the state over the past decades, socioeconomic factors are not been carried out. In this view, the study was designed with the specific objectives to identify and determine the independent variables or characteristics affecting the values towards adoption and reinvention of cultivation practices and to study the relationships and interdependency between personal and socio-economic of the respondents.

\section{Materials and Methods}

The area of investigation of this study is situated in the state of Tripura located in the northeastern part of India. The purposive as well as simple random sampling techniques were adopted for the study. It may be termed as multistage random sampling procedure. The districts, blocks and villages were purposively selected for the study. The Dhalai district and the block Manu were considered. Under the Manu block Moinama, Lambabil and Kukilmani villages were selected. From these villages 77 respondents were selected by using random sampling method. The data were collected using pretested structured schedule by personal interview method. Age $\left(\mathrm{X}_{1}\right)$, Education $\left(\mathrm{X}_{2}\right)$, Family size $\left(\mathrm{X}_{3}\right)$, Farm mechanization $\left(\mathrm{X}_{4}\right)$, Cropping intensity $\left(\mathrm{X}_{5}\right)$, Homestead $\left(\mathrm{X}_{6}\right)$, Own land $\left(\mathrm{X}_{7}\right)$, Area under rubber $\left(\mathrm{X}_{8}\right)$, Annual income-farm $\left(\mathrm{X}_{9}\right)$, Income from rubber $\left(\mathrm{X}_{10}\right)$, Annual-income off farm $\left(\mathrm{X}_{11}\right)$, Economic status $\left(\mathrm{X}_{12}\right)$, Material possession $\left(\mathrm{X}_{13}\right)$, Scientific orientation $\left(\mathrm{X}_{14}\right)$, Orientation towards adoption $\left(\mathrm{X}_{15}\right)$ were selected as independent variables for the purpose of the study. Dependent variable value towards adoption $\left(\mathrm{Y}_{1}\right)$ has been measured using Likert scale with scores of items and categories ranging from strongly agree to strongly disagree and Re-invention $\left(\mathrm{Y}_{2}\right)$ was measured with the scale consists of few statements made by respondents and each statement was of 10 point scale and asked to the respondents to give preference score out of 10. In both dependent variables, the score for each respondent were obtained by summating the score for each statement divided by total statement. Statistical tools namely correlation and regression analysis is used for the study purpose.

\section{Results and Discussion}

The data in Table 1 revealed that out of total growers, majority $(75.32 \%)$ of the respondents fall under 'medium' adoption category, whereas 10.39 per cent and 14.29 per cent are fall under 'low' and 'high' adoption category status respectively.

\section{Co-efficient of correlation analysis}

Acquiring knowledge and adoption of technologies are the multiple functions of personal, social, psychological and economic attributes associated with the individuals.

These attributes either alone or in combination attributed for the desire, conviction and action towards adoption of improved practices. Attempt was therefore made in the study to analyze the interrelationship of some selected variables covered under study.

It is revealed from the Table 2 that the variables namely Age $\left(\mathrm{X}_{1}\right)$, Education $\left(\mathrm{X}_{2}\right)$ and Farm mechanization $\left(\mathrm{X}_{4}\right)$ of the respondents has been found positive and significant correlation with the values towards adoption of rubber cultivation technologies. The positive coefficient of educational level implied that the increase in age, educational and farm mechanization level of respondents showed a relationship to an increase in tendency towards adoption of technology. The result is in agreement with the result of Rajput and Saxena (2002) for education. 
Similar findings were reported by Augustine et al., (2008) This table also reveals that some variables namely Annual income $\left(\mathrm{X}_{9}\right)$ and Economic status $\left(\mathrm{X}_{12}\right)$ have shown significant but, negatively correlation with values towards adoption of scientific rubber cultivation practices which means decrease in annual income and economic status of the respondents are related to the not adopting the available rubber plantation technology.

\section{Multiple regression analysis}

Regression is the determination of a statistical relationship between two or more variables further attempt have been made to locate the important socio-economic variables to assess the causal impact on the consequent factors. The results obtained from the multiple regression analysis have been reflected in Table below

Table.1 Distribution of respondents according to adoption category

\begin{tabular}{lcc}
\hline Category & Numbers & Percentage \\
\hline Low adoption & 8 & 10.39 \\
Medium adoption & 58 & 75.32 \\
High adoption & 11 & 14.29 \\
Total & 77 & 100 \\
\hline
\end{tabular}

Mean=24.76 $\mathrm{SD}=16.14$ and $\mathrm{CV}=65.18$

Table.2 Co-efficient of correlation between values toward adoption ( $\left.\mathrm{Y}_{1}\right)$ with independent variables

\begin{tabular}{|l|c|}
\hline \multicolumn{1}{|c|}{ Variables } & r value \\
\hline 1.Age $\left(\mathrm{X}_{1}\right)$ & $\mathbf{- 0 . 2 6 1} *$ \\
\hline 2.Education $\left(\mathrm{X}_{2}\right)$ & $\mathbf{. 2 4 9}$ \\
\hline 3.Family size $\left(\mathrm{X}_{3}\right)$ & .138 \\
\hline 4.Farm mechanization $\left(\mathrm{X}_{4}\right)$ & $\mathbf{. 2 6 8}$ \\
\hline 5.Cropping intensity $\left(\mathrm{X}_{5}\right)$ & -.096 \\
\hline 6..Homestead land $\left(\mathrm{X}_{6}\right)$ & -.016 \\
\hline 7.Own land $\left(\mathrm{X}_{7}\right)$ & -.079 \\
\hline 8.Area under Rubber $\left(\mathrm{X}_{8}\right)$ & -.071 \\
\hline 9.Annual income $\left(\mathrm{X}_{9}\right)$ & $\mathbf{- . 2 5 5 *}$ \\
\hline 10. Income from rubber $\left.\mathrm{X}_{10}\right)$ & -.058 \\
\hline 11.Off farm income $\left.\mathrm{X}_{11}\right)$ & .173 \\
\hline 12.Economic status $\left(\mathrm{X}_{12}\right)$ & $\mathbf{- 0 . 3 1 5 * *}$ \\
\hline 13.Material possession $\left.\mathrm{X}_{13}\right)$ & .072 \\
\hline 14.Scientific orientation $\left(\mathrm{X}_{14}\right)$ & .105 \\
\hline nificant at 5\% level of probability, $*$ Significant at 1\% level of probability
\end{tabular}


Table.3 Regression analysis: causal effect of independent variables on values towards adoption the consequent variable

\begin{tabular}{|l|c|c|c|}
\hline \multicolumn{1}{|c|}{ Variables } & $\boldsymbol{\beta}$-Value & Regression Co-efficient & t-Value \\
\hline 1. Age $\left(\mathrm{X}_{1}\right)$ & .153 & .007 & .886 \\
\hline 2.Education $\left(\mathrm{X}_{2}\right)$ & .293 & .131 & 1.631 \\
\hline 3.Family size $\left(\mathrm{X}_{3}\right)$ & .122 & .041 & .678 \\
\hline 4.Farm mechanization $\left(\mathrm{X}_{4}\right)$ & .259 & .023 & $\mathbf{2 . 0 5 9 *}$ \\
\hline 5.Cropping Intensity $\left(\mathrm{X}_{5}\right)$ & -.152 & -.003 & -1.141 \\
\hline 6.Homestead land $\left(\mathrm{X}_{6}\right)$ & .017 & .031 & .135 \\
\hline 7. Own land $\left(\mathrm{X}_{7}\right)$ & .056 & .027 & .255 \\
\hline 8. Area under Rubber $\left(\mathrm{X}_{8}\right)$ & -.107 & -.072 & -.413 \\
\hline 9. Annual Income $\left(\mathrm{X}_{9}\right)$ & -.215 & $-1.185 \mathrm{E}-5$ & -1.419 \\
\hline 10. Income from Rubber $\left(\mathrm{X}_{10}\right)$ & .139 & $1.040 \mathrm{E}-5$ & .709 \\
\hline 11. Off-farm income $\left(\mathrm{X}_{11}\right)$ & .124 & $2.274 \mathrm{E}-5$ & .939 \\
\hline 12. Economic status $\left(\mathrm{X}_{12}\right)$ & .033 & .141 & .234 \\
\hline 13. Material possession $\left(\mathrm{X}_{13}\right)$ & -.009 & $-3.462 \mathrm{E}-6$ & -.070 \\
\hline 14. Scientific Orientation $\left(\mathrm{X}_{14}\right)$ & -.005 & -.005 & -.039 \\
\hline
\end{tabular}

$\mathrm{R}$ square $=0.627$, Adjusted R square $=0.052, *$ Significant at $5 \%$ level of probability

Table.4 Co-efficient of correlation between Re-invention $\left(\mathrm{Y}_{2}\right)$ with Independent Variables

\begin{tabular}{|l|c|}
\hline \multicolumn{1}{|c|}{ Variables } & r value \\
\hline 1. Age $\left(\mathrm{X}_{1}\right)$ & -0.193 \\
\hline 2.Education $\left(\mathrm{X}_{2}\right)$ & $\mathbf{0 . 2 4 8}$ \\
\hline 3.Family size $\left(\mathrm{X}_{3}\right)$ & 0.088 \\
\hline 4.Farm mechanization $\left(\mathrm{X}_{4}\right)$ & 0.052 \\
\hline 5.Cropping Intensity $\left(\mathrm{X}_{5}\right)$ & 0.158 \\
\hline 6.Homestead land $\left(\mathrm{X}_{6}\right)$ & -0.265 \\
\hline 7. Own land $\left(\mathrm{X}_{7}\right)$ & -0.014 \\
\hline 8. Area under Rubber $\left(\mathrm{X}_{8}\right)$ & -0.038 \\
\hline 9. Annual Income $\left(\mathrm{X}_{9}\right)$ & -0.033 \\
\hline 10. Income from Rubber $\left(\mathrm{X}_{10}\right)$ & -0.014 \\
\hline 11. Off-farm income $\left(\mathrm{X}_{11}\right)$ & $\mathbf{0 . 2 5 5}$ \\
\hline 12. Economic status $\left(\mathrm{X}_{12}\right)$ & -0.173 \\
\hline 13. Material possession $\left(\mathrm{X}_{13}\right)$ & 0.002 \\
\hline 14. Scientific Orientation $\left(\mathrm{X}_{14}\right)$ & 0.047 \\
\hline
\end{tabular}

* Significant at $5 \%$ level of probability 
Table.5 Regression analysis: causal effect of independent variables on re invention the consequent variable

\begin{tabular}{|l|c|c|c|}
\hline \multicolumn{1}{|c|}{ Variables } & $\boldsymbol{\beta}$-Value & Regression Co-efficient & t-Value \\
\hline 1. Age $\left(\mathrm{X}_{1}\right)$ & -0.202 & -0.008 & -1.133 \\
\hline 2.Education $\left(\mathrm{X}_{2}\right)$ & 0.000 & 0.000 & 0.003 \\
\hline 3.Family size $\left(\mathrm{X}_{3}\right)$ & 0.396 & 0.120 & $\mathbf{2 . 2 2 9}$ \\
\hline 4.Farm mechanization $\left(\mathrm{X}_{4}\right)$ & -0.173 & -0.014 & -1.298 \\
\hline 5.Cropping Intensity $\left(\mathrm{X}_{5}\right)$ & 0.142 & 0.002 & 1.037 \\
\hline 6.Homestead land $\left(\mathrm{X}_{6}\right)$ & -0.209 & -0.339 & -1.555 \\
\hline 7. Own land $\left(\mathrm{X}_{7}\right)$ & 0.146 & 0.062 & 0.654 \\
\hline 8. Area under Rubber $\left(\mathrm{X}_{8}\right)$ & 0.129 & 0.077 & 0.489 \\
\hline 9. Annual Income $\left(\mathrm{X}_{9}\right)$ & 0.031 & 0.015 & 0.183 \\
\hline 10. Income from Rubber $\left(\mathrm{X}_{10}\right)$ & 0.093 & 0.062 & 0.461 \\
\hline 11. Off-farm income $\left(\mathrm{X}_{11}\right)$ & 0.297 & 0.048 & 2.238 \\
\hline 12. Economic status $\left(\mathrm{X}_{12}\right)$ & -0.167 & -0.642 & -1.192 \\
\hline 13. Material possession $\left(\mathrm{X}_{13}\right)$ & -0.132 & -0.043 & -0.940 \\
\hline 14. Scientific Orientation $\left(\mathrm{X}_{14}\right)$ & -0.077 & -0.072 & -0.593 \\
\hline
\end{tabular}

$\mathrm{R}$ square $=0.511$, Adjusted R square $=0.097, *$ Significant at $5 \%$ level probability

Table 3 reveals that causal variable farm mechanization $\left(\mathrm{X}_{4}\right)$ has been found significant and can be stated as adoption towards rubber technology is affected by how well the rubber farming is mechanized. $\mathrm{R}^{2}$ value being 0.627 , it is concluded that with the combination of all these 14 causal variables, 62.7 per cent variance in values toward adoption has been explained.

The data revealed that the best fitted regression equation could explain $62.7 \%$ of the total variance in influencing the in values toward adoption of respondents.

It is concluded from Table 4 that causal variables Education $\left(\mathrm{X}_{2}\right)$ and Off-farm income $\left(\mathrm{X}_{11}\right)$ of the respondents has been found positive and significant correlation with the re-invention that respondents having higher level of education and off farm income are more prone towards re-invention of cultivation practices

Table 5 presents the causal effect of independent variables on re-invention. The variable family $\operatorname{size}\left(\mathrm{X}_{3}\right)$ has got highest percentile contribution to re-invention of rubber farming technology which indicates reinvention of cultivation practices are decisively influenced by family size. $\mathrm{R}^{2}$ value being 0.511, it is concluded that with the combination of all these 14 causal variables, 51.1 per cent variance in re-invention has been explained.

The outcome of the study reveals that farm mechanization, economic status, and annual income and off farm income are found to be the major determining factor in values towards adoption and re-invention of cultivation technologies. Among personal and socio-psychological variables age and education are also found to be significant.

Thus, it can be suggested that those significant variables under rubber farming systems need to given due attention and concerted efforts while formulating various developmental strategies and programmes which in turn will benefit the large section of farming community at large. 


\section{References}

Augustine, J. U., Anietie, I., Emmanuel, U. and Unyime, R. 2008. Socioeconomic Factors Influencing Adoption of Yam Minisett Technology in South eastern Nigeria: A Probit Analysis. Indian Res. J. Ext. Edu. 8 (2\&3) pp 1-5

Government of Tripura. 2015. Economic Review of Tripura 2013-14.)Pub. Directorate of Economics \& Statistics Planning (Statistics) Department Government of Tripura, Agartala. Available at: www.destripura.nic.in
Rajput, A.M., and Saxena, K.K. 2002. Socioeconomic profile of watershed and nonwatershed area in the watershed development programme. Maharashtra J. Ext. Edu. 21(1): 36-40.

Viswanathan, P.K., and Indraneel, B. 2014. 'Compatibility of Institutional Architecture for Rubber Plantation Development in North East India from a Comparative Perspective of Kerala', NRPPD Discussion Paper 38, Centre for Development Studies, Trivandrum, pp 65-71.

\section{How to cite this article:}

Kharendra Reang, Samir Ranjan Dash and Amitava Biswas. 2017. Correlates Attitude towards Adoption and Re-Invention Technology of Small Rubber Farmers in Dhalai District of Tripura, India. Int.J.Curr.Microbiol.App.Sci. 6(10): 3145-3150.

doi: https://doi.org/10.20546/ijcmas.2017.610.369 